\title{
The use of chestnuts (Castanea sativa Mill.) as a source of resistant starch in the diet of the weaned piglet
}

\author{
R.S. Ribeiro ${ }^{a}$, M. Pinho ${ }^{b}$, L. Falcão-Cunha ${ }^{a}$, J.P.B. Freire ${ }^{a}, *$ \\ a CEER, Instituto Superior de Agronomia, Universidade Técnica de Lisboa, Tapada da Ajuda, 1349-017 Lisboa, Portugal \\ b CIISA, Faculdade de Medicina Veterinária, Universidade Técnica de Lisboa, Avenida da Universidade Técnica, 1300-477 Lisboa, Portugal
}

\section{A R T I C L E I N F O}

\section{Article history:}

Received 21 January 2013

Received in revised form 12 April 2013

Accepted 15 April 2013

Available online $\mathrm{xxx}$

\section{Keywords:}

Bacterial activity

Chestnuts

Digestibility

Intestinal morphology

Piglets

Resistant starch

\begin{abstract}
A B S T R A C T
Twenty-four piglets, with a mean weight of $6.11 \mathrm{~kg}$, were allocated to three experimental diets (8 piglets per diet). The starch content of the experimental diets was $39 \%$ consisting either of $100 \%$ wheat starch (CD), $50 \%$ wheat starch and $50 \%$ chestnut starch (CN50) or $100 \%$ chestnut starch (CN100). The piglets received these diets for 35 days. Total tract apparent digestibility (TTAD) was measured when piglets were aged 32-39 days and 46-53 days. Afterwards, the animals were sacrificed, their gastrointestinal compartments weighed, and the contents of their caecum and colon collected. Diet did not influence the feed intake or growth rate of the piglets, but had a significant effect on their feed conversion ratio which was $1.27,1.30$ and 1.37 for diets $C D, C N 50$ and $C N 100$, respectively ( $P=0.042$ ). Piglets receiving the $\mathrm{CN} 50$ diet exhibited lower faecal scores compared to $\mathrm{CD}$ and $\mathrm{CN} 100$ groups $\left(\chi^{2}=39.31, \mathrm{P}<0.001\right)$. There was a trend $(\mathrm{P}=0.067)$ towards an increase in the TTAD of dry matter (DM) in the two chestnut-containing diets, but only when piglets were younger (32-39 days). The TTAD of crude protein $(\mathrm{CP})$ was decreased $(\mathrm{P}<0.001)$ in $\mathrm{CN} 100$ group relative to $\mathrm{CD}$ and $\mathrm{CN} 50$ groups, independently of age. Relative to the $\mathrm{CD}$ group, the coefficient of TTAD of NDF was increased by 0.18 units in the CN50 group and 0.25 units in the CN100 group, when the piglets were aged 32-39 days. These differences were reduced to 0.09 and 0.17 units, respectively, when the piglets were aged $46-53$ days. There were tendencies $(\mathrm{P}<0.10)$ towards increases in the full and empty weights of the large intestine in $\mathrm{CN} 100$ group. Moreover, diet had no significant effect on villus height and width. In the jejunum, crypt depth was reduced in $\mathrm{CN} 100$ group $(\mathrm{P}=0.006)$, while the villus height: crypt depth ratio was increased with the $\mathrm{CN} 50$ and $\mathrm{CN} 100$ diets $(\mathrm{P}=0.018)$. Diet had no significant effect on $\mathrm{DM}$ and $\mathrm{pH}$ of the caecal or colonic contents. In the caecum, the concentration ( $\mathrm{mmol} \mathrm{l}^{-1}$ ) of propionic acid was $5.15,9.43$ and $14.7(\mathrm{P}=0.042$ ) for diets $\mathrm{CD}, \mathrm{CN} 50$ and $\mathrm{CN} 100$, respectively. The concentration $\left(\mathrm{mmol}^{-1}\right)$ of butyric acid was $3.50,4.90$ and $9.84(\mathrm{P}=0.025)$. Conversely, diet had no significant effect on the concentration of short chain fatty acids in the colon. In conclusion, chestnuts could be used as an alternative source of RS in the diet of weaned piglets, although their feed conversion ratio (FCR) may be worsened.
\end{abstract}

(c) 2013 Elsevier B.V. All rights reserved.

\footnotetext{
Abbreviations: ADFom, acid detergent fibre expressed exclusive of residual ash; ADL, acid detergent lignin; aNDFom, neutral detergent fibre assayed with heat stable amylase and expressed exclusive of residual ash; CD, control diet; CN50, diet containing 50\% wheat starch and 50\% chestnut starch; CN100, diet containing 100\% chestnut starch; CP, crude protein; CTTAD, coefficient of total tract apparent digestibility; DM, dry matter; FCR, feed conversion ratio; LR, Landrace; NDF, neutral detergent fibre; NSP, non-starch polysaccharides; RDS, rapidly digestible starch; RS, resistant starch; SCFAs, short chain fatty acids; SD, standard deviation; SDS, slowly digestible starch; TDF, total dietary fibre; TTAD, total tract apparent digestibility.

* Corresponding author. Tel.: +351 213653408.

E-mail address: jpfreire@isa.utl.pt (J.P.B. Freire).
} 


\section{Introduction}

The chestnut (Castanea sativa Mill.) is a traditional nut from European Mediterranean countries, and one of the most popular in the world. In Europe, Portugal is one of the biggest producers; in 2010, it produced approximately 22,000 tonnes, representing $3 \%$ of world production (INE, 2011).

Starch accounts for $50-80 \%$ of the dry matter content of European chestnuts cultivars, while protein represents between 6.0 and 8.6\% (Míguelez et al., 2004). According to Pizzoferrato et al. (1999), 21.5\% of raw chestnut starch takes the form of rapidly digestible starch (RDS), $20.9 \%$ is slowly digestible starch (SDS), and 57.6\% can be termed resistant starch (RS).

Resistant starch provides a fermentable substrate for caecal and colonic microflora. Thus, including RS in the diet will influence microbial metabolism in the large intestine; increasing the size of the bifidobacteria and lactobacilli populations (Bird et al., 2007). Recently, it was shown that including 7\% of raw potato starch (as a source of RS) in the diet of weaned piglets improved their faecal scores, and modified the Bacteroidetes, Firmicutes and Proteobacteria populations in the colon but not in the ileum (Bhandari et al., 2009). These prebiotic actions are comparable to those of established prebiotic oligosaccharides, notably the insulin-type fructans (Robertfroid, 2001).

In the large intestine of piglets, the concentration of short chain fatty acids (SCFAs) - in particular butyrate - increases with the inclusion of RS in the diet (Hedemann and Bach Knudsen, 2007). Moreover, dietary RS has been shown to prevent pathogen infections and diarrhoea in monogastric animals (Williams et al., 2001), and to improve colonic mucosal morphology and integrity (Hedemann and Bach Knudsen, 2007; Nofrarías et al., 2007).

In pigs, dietary RS increases faecal nitrogen excretion and decreases the total tract apparent digestibility (TTAD) of crude protein (CP) (Rideout et al., 2008). Seemingly, the increase in faecal nitrogen after RS consumption is not due to any effect on the secretion of mucin or endogenous nitrogen in the small intestine (Morel et al., 2005). Instead, it can be attributed to an increase in bacterial nitrogen through the stimulation of bacterial growth in the hindgut (Heijnen and Beynen, 1997).

In the present study, chestnuts were used as an alternative source of RS in the diet of weaned piglets. Control animals were fed a standard diet containing $100 \%$ wheat starch, while experimental animals received one of two alternative diets. One diet contained $50 \%$ wheat starch and $50 \%$ chestnut starch, while the other contained $100 \%$ chestnut starch. The objective was to determine the effect of these diets on growth performance, total tract apparent digestibility, small intestine mucosal morphology and hindgut microbial activity.

\section{Materials and methods}

\subsection{Animals and housing}

Twenty-four male piglets (Duroc $\times$ LR), weaned at 3 weeks of age, with a mean weight of $6.11 \mathrm{~kg}(\mathrm{SD}=0.49 \mathrm{~kg}$ ) were used. Piglets were assigned to 3 groups ( 8 piglets per group), according to live weight. Each group received one of three experimental diets. Animals were individually housed in metabolic cages $(110 \mathrm{~cm} \times 80 \mathrm{~cm})$ equipped with stainless steel plates for separate collection of faeces and urine. Room temperature was initially set at $28^{\circ} \mathrm{C}$, and was decreased by $2{ }^{\circ} \mathrm{C}$ each week until it reached a final temperature of $24^{\circ} \mathrm{C}$.

After an acclimatization period of three days, the piglets completed 5 weeks ( 35 days) of experimental observation. Piglets were weighed at the beginning of each week, and faeces were collected during two periods of 7 days (second and fourth experimental weeks) to calculate TTAD. The consistency of the faecal matter was recorded daily, according to the scale proposed by Marquardt et al. (1999): $0=$ normal, $1=$ soft faeces, $2=$ moderate diarrhoea and $3=$ liquid diarrhoea.

At the end of the experiment, the piglets were sacrificed in the morning (08:00) by electrocution following $12 \mathrm{~h}$ of food deprivation. The weight of the pancreas, the liver, and the compartments of the gastrointestinal tract were then recorded. The length of the small and large intestine was also measured. The contents of the caecum and colon were immediately collected for the analysis of pH, DM content, microbial enzymatic activity and levels of SCFAs. Tissue samples from three segments of the small intestine were also collected: the duodenum $(10 \mathrm{~cm}$ from the pylorus), jejunum $(5.5 \mathrm{~m}$ from the pylorus) and ileum ( $60 \mathrm{~cm}$ before the ileo-cecal valve). The tissue samples were fixed in $10 \%$ neutral buffered formalin, embedded in paraffin wax, and then sectioned and mounted for microscopic examination of the intestinal villi and crypts.

\subsection{Chestnuts preparation and diets formulation}

Fresh chestnuts were obtained and mechanically peeled to remove the tegument and pericarp. The chestnuts were then dried at $40^{\circ} \mathrm{C}$ for $48 \mathrm{~h}$. This reduced their moisture content from around $50 \%$ to $10-12 \%$. The dried chestnuts were milled through a $2 \mathrm{~mm}$ screen before they were added to the diets. Their chemical composition is reported in Table 1 . Three experimental diets were prepared (Table 2). The starch content of the experimental diets was 39\%; consisting of either $100 \%$ wheat starch $(C D), 50 \%$ wheat starch and $50 \%$ chestnut starch $(C N 50)$, or $100 \%$ chestnut starch $(C N 100)$. The diets were formulated according to the NRC (1998) recommendations for 5-20 kg piglets. They were pelleted $(3 \mathrm{~mm})$ and given to the piglets on a single meal per day basis. Animals had access to water ad libitum. 
Table 1

Chemical composition of wheat and chestnuts $\left(\mathrm{g} \mathrm{kg}^{-1}\right)$.

\begin{tabular}{lcc}
\hline & Wheat & Chestnuts $^{\mathrm{a}}$ \\
\hline Dry matter & 863 & 881 \\
Crude protein & 99.3 & 60.1 \\
Starch & 586 & 625 \\
TDFb & 123 & 141 \\
aNDFom $^{\mathrm{c}}$ & 121 & 170 \\
ADFom $^{\mathrm{d}}$ & 24.3 & 32.6 \\
\hline
\end{tabular}

a Dried at $40^{\circ} \mathrm{C}$.

b $\mathrm{TDF}$ = total dietary fibre, determined using a gravimetric-enzymatic procedure and expressed exclusive of protein and ash.

c aNDFom = neutral detergent fibre assayed with heat stable amylase and expressed exclusive of residual ash.

d ADFom = acid detergent fibre expressed exclusive of residual ash.

\subsection{Chemical analysis}

After collection, faeces were dried at $70^{\circ} \mathrm{C}$ for $48 \mathrm{~h}$. Dried faeces and feed samples were milled through a $1 \mathrm{~mm}$ screen prior to analysis. For both faeces and feed samples, DM content was determined by oven drying at $104{ }^{\circ} \mathrm{C}$ for $24 \mathrm{~h}$. Ash content was determined by burning overnight at $550^{\circ} \mathrm{C}$. CP was measured using the Kjeldahl method (976.95; AOAC, 1995).

Analysis of neutral detergent fibre (aNDFfom), acid detergent fibre (ADFfom) and acid detergent lignin (ADL) was performed sequentially using the crucibles system, and expressed without residual ash. For feed samples, a thermo-stable $\alpha$-amylase was used (Van Soest et al., 1991). Total dietary fibre (TDF) in the wheat and chestnuts was determined with a gravimetric-enzymatic procedure (AOAC, 2000, 991.43), using $\alpha$-amylase, protease, and amyloglucosidase treatments (Megazyme Int. Ireland Ltd., Wicklow, Ireland). The starch content of the diets, wheat and chestnuts was analyzed enzymatically according to the method described by Thivend et al. (1965).

The $\mathrm{pH}$ of the intestinal contents was measured with a glass electrode $\mathrm{pH}$ metre (Metrohm $744 \mathrm{~m}$ ). SCFAs (acetic acid (C2), propionic acid (C3) and butyric acid (C4)) and branch fatty acids (isobutyric acid (IC4) and isovaleric acid (IC5)) were quantified in the caecal and colonic contents by gas chromatography, following the methods outlined by Freire et al. (2003).

Bacterial fibre (cellulolytic, xylanolytic and pectinolytic) degradation in the caecal and colonic contents were measured as described by Falcão-e-Cunha et al. (2004), and expressed as the quantity of sugars (mg) liberated after one hour of incubation at $37^{\circ} \mathrm{C}$.

Table 2

Composition of the experimental diets.

\begin{tabular}{|c|c|c|c|}
\hline & \multicolumn{3}{|l|}{ Diets } \\
\hline & $\mathrm{CD}$ & CN50 & CN100 \\
\hline \multicolumn{4}{|l|}{ Ingredients $\left(\mathrm{g} \mathrm{kg}^{-1}\right)$} \\
\hline Wheat & 661 & 341 & - \\
\hline Chestnuts $^{\mathrm{a}}$ & - & 310 & 631 \\
\hline Soybean meal 48 & 160 & 160 & 160 \\
\hline Dried whey & 50.0 & 50.0 & 50.0 \\
\hline Fish meal & 70.0 & 80.0 & 100 \\
\hline Soybean oil & 30.0 & 30.0 & 30.0 \\
\hline L-Lysine & 4.0 & 4.0 & 4.0 \\
\hline DL-Methionine & 2.0 & 2.0 & 2.0 \\
\hline Calcium carbonate & 7.0 & 7.0 & 7.0 \\
\hline Dicalcium phosphate & 9.0 & 9.0 & 9.0 \\
\hline Sodium chloride & 2.0 & 2.0 & 2.0 \\
\hline $\mathrm{MVC}^{\mathrm{b}}$ & 5.0 & 5.0 & 5.0 \\
\hline \multicolumn{4}{|c|}{ Chemical composition $\left(\mathrm{g} \mathrm{kg}^{-1}\right.$ ) } \\
\hline Dry matter & 909 & 911 & 919 \\
\hline Organic matter & 853 & 854 & 856 \\
\hline Ash & 56.0 & 57.4 & 60.9 \\
\hline Crude protein & 225 & 214 & 213 \\
\hline aNDFom $^{c}$ & 104 & 123 & 110 \\
\hline ADFom $^{\mathrm{d}}$ & 32.2 & 33.0 & 37.5 \\
\hline $\mathrm{ADL}^{\mathrm{e}}$ & 7.8 & 10.6 & 9.0 \\
\hline Starch & 390 & 395 & 394 \\
\hline
\end{tabular}

a Dried at $40^{\circ} \mathrm{C}$.

b Mineral and vitamin complex. Composition by kg of feed: Vit. A: 25000 UI; Vit. D3: 2000 UI; Vit. E: 20 UI; Vit. C: 200 mg; Vit. B1: 1, 5 mg; Vit. B2: $5 \mathrm{mg}$; Vit. B3:30 mg; Vit. B5: $15 \mathrm{mg}$; Vit. B6: 2, $5 \mathrm{mg}$; Vit. B9: 0, $5 \mathrm{mg}$; Vit. B12: 0, $03 \mathrm{mg}$; Vit. K3: $1 \mathrm{mg}$; Vit. H2: $80 \mathrm{mg}$; coline: $300 \mathrm{mg}$; (potassium iodate): $1 \mathrm{mg}$; Mn (manganous oxide): $50 \mathrm{mg}$; Fe (ferrous carbonate): $120 \mathrm{mg} ; \mathrm{Zn}$ (zinc oxide): $140 \mathrm{mg}$; Cu (cupric sulfate): $160 \mathrm{mg} ; \mathrm{Se}$ (sodium selenite): $0.3 \mathrm{mg}$; Co (cobalt carbonate): $0.5 \mathrm{mg}$.

${ }^{c}$ aNDFom $=$ neutral detergent fibre assayed with heat stable amylase and expressed exclusive of residual ash.

d $\mathrm{ADFom}=$ acid detergent fibre expressed exclusive of residual ash.

e $\mathrm{ADL}=$ acid detergent lignin. 
Table 3

Effect of dietary proportion of chestnuts on growth performance and faecal scores of piglets fed different amounts of chestnuts for 35 days post-weaning.

\begin{tabular}{|c|c|c|c|c|c|c|}
\hline & \multicolumn{3}{|l|}{ Diet } & \multirow[t]{2}{*}{$\mathrm{SEM}^{\mathrm{A}}$} & \multirow[t]{2}{*}{$\mathrm{X} 2^{\mathrm{A}}$} & \multirow[t]{2}{*}{$\mathrm{P}^{\mathrm{A}}$} \\
\hline & $\mathrm{CD}$ & CN50 & CN100 & & & \\
\hline Initial weight (kg) & 6.05 & 6.10 & 6.19 & 0.10 & - & 0.840 \\
\hline Final weight (kg) & 17.3 & 18.1 & 16.9 & 0.34 & - & 0.425 \\
\hline Intake $\left(\mathrm{g} \mathrm{d}^{-1}\right)$ & 509 & 558 & 520 & 10.0 & - & 0.169 \\
\hline Growth rate $\left(\mathrm{g} \mathrm{d}^{-1}\right)$ & 402 & 428 & 384 & 10.7 & - & 0.271 \\
\hline $\mathrm{FCR}^{\mathrm{B}}$ & $1.27^{\mathrm{a}}$ & $1.30^{\mathrm{a}, \mathrm{b}}$ & $1.37^{\mathrm{b}}$ & 0.02 & - & 0.042 \\
\hline Faecal score ${ }^{C}$ & 1.43 & 0.86 & 1.03 & 0.04 & 39.31 & $<0.001$ \\
\hline
\end{tabular}

A X2: Pearson chi-squared test. P values for the effect of diet. SEM: standard error of the mean ( $n=24$ for growth performances, $n=840$ for faecal score). $\mathrm{a}, \mathrm{b}$ : in the same line, values with the same letter are not significantly different $(\mathrm{P}>0.05)$.

B Feed conversion ratio.

C $0=$ normal, 1 = soft faeces, 2 = moderate diarrhoea and 3 = liquid diarrhoea.

Microscopic examination and measurement of villi heights and widths and crypt depths were performed in $7 \mu \mathrm{m}$ thick tissue sections, stained with haematoxylin-eosin. An Olympus BX 511 microscope equipped with $4 \times$ and $10 \times$ lenses was used. Images were digitally captured with an Olympus DP 11 camera. The height and width of the villi and the depth of the crypts were measured using the Olympus DP-Soft software. Ten intact and correctly oriented villi and crypts from each intestinal region were selected for each piglet.

\subsection{Statistical analysis}

Data were subjected to analysis of variance (ANOVA), with diet as the main factor. All statistical analyses were conducted with the $S A S^{\circledR}$ statistical software package (SAS, 1991). Digestibility data were analyzed with the MIXED procedure of SAS, to consider repeated measures in time (Littell et al., 1998). The faecal scores were compared with a chi-squared test, using the FREQ procedure of SAS. All other data were analyzed with the GLM procedure of SAS, according to a complete block design. When the $F$-value in the ANOVA was significant, least squares means were compared by the least significant difference. A difference was considered significant if the P-value was less than 0.05 .

\section{Results}

\subsection{Growth performance and consistency of faeces}

As shown in Table 3, the mean initial weight of the piglets was $6.11 \mathrm{~kg}$ and the mean final weight was $17.44 \mathrm{~kg}$. Diet had no significant effect on the daily feed intake and the daily growth rate. The mean value of these traits was $529 \mathrm{~g}$ and $404 \mathrm{~g}$, respectively.

The piglets in the CN100 group were the least efficient users of feed; the feed conversion ratio (FCR) was 0.10 points higher in the $\mathrm{CN} 100$ group relative to the $\mathrm{CD}$ group $(\mathrm{P}=0.042$ ).

Average faecal score was 1.43, 0.86 and 1.03 for piglets from groups CD, CN50 and CN100, respectively. Thus, there was a trend towards lower faecal scores amongst piglets receiving the CN50 diet compared to the CD and CN100 diets, indicating a better consistency of faeces and a lower incidence of soft faeces in these animals.

\subsection{Total tract apparent digestibility (TTAD)}

The effects of diet and age on TTAD are depicted in Table 4. There was a tendency ( $\mathrm{P}=0.067)$ towards an increase in the TTAD of DM in the two chestnut-containing diets relative to the control diet, but only when the piglets were younger (aged 32-39 days). Consequently, there was a significant diet $\times$ age interaction effect on the TTAD of DM ( $P=0.019)$.

On the contrary, the TTAD of $C P$ was reduced $(\mathrm{P}<0.001)$ in the $\mathrm{CN} 100$ group relative to the $\mathrm{CD}$ and $\mathrm{CN} 50$ groups, independently of age. The coefficients of total tract apparent digestibility (CTTAD) of CP were $0.84,0.83$ and 0.79 in groups CD, CN50 and $\mathrm{CN} 100$, respectively, for piglets aged 32-39 days. These coefficients were $0.87,0.82$ and 0.77 for piglets aged $46-53$ days. The TTAD of NDF and ADF were both increased with the inclusion of chestnuts in the diet, although these differences were greater amongst the younger piglets. Relative to the CD group, the coefficient of TTAD of NDF was increased by 0.18 units in the CN50 group and 0.25 units in the CN100 group, when the piglets were aged 32-39 days (period A1). These differences were reduced to 0.09 and 0.17 units, respectively, when the piglets were aged $46-53$ days (period A2). Similarly, the coefficient of TTAD of ADF was increased by 0.24 units with the CN50 diet and by 0.40 units with the CN100 diet during period A1. During period A2, these figures were 0.12 units and 0.28 units, respectively. Finally, the TTAD of the major constituents of the diets were not modified significantly by the age of the piglets. The CTTAD of DM was 0.90 and 0.89 , and the CTTAD of $\mathrm{CP}$ was 0.79 and 0.77 for piglets aged 32-39 days and 46-53 days, respectively. 
Table 4

Effect of dietary proportion of chestnuts and age on total tract apparent digestibility.

\begin{tabular}{|c|c|c|c|c|c|c|c|c|c|c|}
\hline \multirow{2}{*}{$\begin{array}{l}\text { Diet }^{\mathrm{A}} \\
\text { Age }^{\mathrm{B}}\end{array}$} & \multicolumn{2}{|l|}{$\mathrm{CD}$} & \multicolumn{2}{|c|}{ CN50 } & \multicolumn{2}{|c|}{ CN100 } & \multirow[b]{2}{*}{$\mathrm{SEM}^{\mathrm{C}}$} & \multicolumn{3}{|c|}{ P-value ${ }^{\mathrm{D}}$} \\
\hline & A1 & A2 & A1 & A2 & A1 & A2 & & Diet & Age & DxA \\
\hline \multicolumn{11}{|l|}{$\mathrm{CTTAD}^{\mathrm{E}}$} \\
\hline Dry matter & 0.87 & 0.90 & 0.90 & 0.90 & 0.90 & 0.89 & 0.003 & 0.067 & 0.164 & 0.019 \\
\hline Crude protein & 0.84 & 0.87 & 0.83 & 0.82 & 0.79 & 0.77 & 0.007 & $<0.001$ & 0.873 & 0.128 \\
\hline $\mathrm{NDF}^{\mathrm{F}}$ & 0.65 & 0.70 & 0.83 & 0.79 & 0.90 & 0.87 & 0.014 & $<0.001$ & 0.416 & 0.003 \\
\hline $\mathrm{ADF}^{\mathrm{G}}$ & 0.46 & 0.54 & 0.71 & 0.65 & 0.86 & 0.82 & 0.022 & $<0.001$ & 0.743 & 0.009 \\
\hline
\end{tabular}

A CD: control diet containing $100 \%$ wheat starch, CN50: diet containing $50 \%$ wheat starch and $50 \%$ chestnut starch, CN100: diet containing $100 \%$ chestnut starch.

B A1: piglets aged 32-39 days. A2: piglets aged 46-53 days.

C SEM: Standard error of the mean $(n=48)$.

D $P$ values for the effects: diet, age and interaction diet $\times$ age.

E Coefficients of total tract apparent digestibility.

F Neutral detergent fibre.

${ }^{\mathrm{G}}$ Acid detergent fibre.

\subsection{Weight of the gastrointestinal compartments}

The effects of the experimental diets on the development of the gastrointestinal compartments are outlined in Table 5. The inclusion of chestnuts in the diets had no significant effect on the weight ( $\mathrm{g} \mathrm{kg}^{-1}$ live weight) of the full or empty stomach or the small intestine. Nevertheless, there was a tendency towards an increase in the weight of the small intestine contents when piglets were fed with chestnuts, especially in the CN100 group ( $\mathrm{P}=0.090)$.

There were also tendencies $(\mathrm{P}<0.10)$ towards increases in the full and empty weights of the large intestine in the $\mathrm{CN} 100$ group. The increase in full weight was roughly $19 \%$ relative to the CD group, and $15 \%$ relative to the CN50 group. For the empty weight, these values were about $11 \%$ and $21 \%$, respectively.

Finally, the experimental diets had no significant effect on the relative weights of the pancreas or liver.

\subsection{Morphology of the small intestine mucosa}

The experimental diets had no significant effect $(\mathrm{P}>0.05)$ on villus height and width in the duodenum, jejunum or ileum of the piglets (Table 6). Similarly the crypt depth and the villus height:crypt depth ratio in the duodenum or ileum were not significantly affected by the experimental diets. However, crypt depth in the jejunum was decreased in the CN100 group $(\mathrm{P}=0.006)$; it was reduced by $26 \%$ relative to the $C D$ group and $19 \%$ relative to the CN50 group. There was also a tendency towards decreased crypt depth in the duodenum in the $\mathrm{CN} 100$ group $(\mathrm{P}=0.059)$; it was reduced by $12 \%$ relative to the other experimental diets.

In addition, the villus height:crypt depth ratio in the jejunum of piglets in the CD group was $22 \%$ and $73 \%$ lower than in the CN50 and CN100 groups, respectively ( $\mathrm{P}=0.018)$. With the CN100 diet, the increase in the villus height:crypt depth ratio in the duodenum was close to reach statistical significance $(\mathrm{P}=0.055)$.

Table 5

Effect of dietary proportion of chestnuts on the relative weight ( $\mathrm{g} \mathrm{kg}^{-1}$ of live weight) of the gastrointestinal tract, pancreas and liver of piglets.

\begin{tabular}{|c|c|c|c|c|c|}
\hline & \multicolumn{3}{|l|}{$\operatorname{Diet}^{A}$} & \multirow[t]{2}{*}{ SEM $^{\mathrm{B}}$} & \multirow[t]{2}{*}{$\mathrm{P}^{\mathrm{B}}$} \\
\hline & $\mathrm{CD}$ & CN50 & CN100 & & \\
\hline \multicolumn{6}{|l|}{ Stomach } \\
\hline Full & 12.5 & 13.0 & 14.3 & 0.51 & 0.358 \\
\hline Empty & 8.55 & 9.12 & 8.77 & 0.17 & 0.394 \\
\hline Content & 3.95 & 3.89 & 5.51 & 0.46 & 0.280 \\
\hline \multicolumn{6}{|l|}{ Small intestine } \\
\hline Full & 54.9 & 54.8 & 58.5 & 1.17 & 0.346 \\
\hline Empty & 45.3 & 43.7 & 44.7 & 0.64 & 0.626 \\
\hline Content & 9.57 & 11.1 & 13.9 & 0.82 & 0.090 \\
\hline Length (m) & 15.2 & 15.5 & 15.4 & 0.21 & 0.842 \\
\hline \multicolumn{6}{|l|}{ Large intestine } \\
\hline Full & 39.9 & 41.3 & 47.6 & 1.45 & 0.067 \\
\hline Empty & 22.0 & 20.2 & 24.5 & 0.76 & 0.059 \\
\hline Content & 17.9 & 21.1 & 23.2 & 1.21 & 0.221 \\
\hline Length (m) & 2.83 & 2.49 & 2.54 & 0.07 & 0.125 \\
\hline Pancreas & 2.37 & 2.29 & 2.21 & 0.07 & 0.634 \\
\hline Liver & 27.3 & 26.7 & 29.8 & 0.86 & 0.314 \\
\hline
\end{tabular}

A CD: control diet containing 100\% wheat starch, CN50: diet containing 50\% wheat starch and 50\% chestnut starch, CN100: diet containing $100 \%$ chestnut starch.

B P values for diet effect. SEM: standard error of the mean $(n=24)$. 
Table 6

Effect of dietary proportion of chestnuts on small intestinal mucosa morphology.

\begin{tabular}{|c|c|c|c|c|c|}
\hline & \multicolumn{3}{|l|}{$\operatorname{Diet}^{A}$} & \multirow[t]{2}{*}{$\mathrm{SEM}^{\mathrm{B}}$} & \multirow[t]{2}{*}{$\mathrm{P}^{\mathrm{B}}$} \\
\hline & $\mathrm{CD}$ & CN50 & CN100 & & \\
\hline \multicolumn{6}{|c|}{ Villus height ( $\mu \mathrm{m})$} \\
\hline Duodenum & 414 & 407 & 421 & 9.25 & 0.875 \\
\hline Jejunum & 374 & 433 & 385 & 13.3 & 0.109 \\
\hline Ileum & 324 & 325 & 319 & 11.2 & 0.985 \\
\hline \multicolumn{6}{|c|}{ Villus width $(\mu \mathrm{m})$} \\
\hline Duodenum & 199 & 229 & 202 & 7.10 & 0.125 \\
\hline Jejunum & 166 & 179 & 172 & 3.83 & 0.327 \\
\hline Ileum & 168 & 189 & 182 & 5.45 & 0.209 \\
\hline \multicolumn{6}{|c|}{ Crypt depth $(\mu \mathrm{m})$} \\
\hline Duodenum & 516 & 520 & 453 & 10.2 & 0.059 \\
\hline Jejunum & $411^{\mathrm{a}}$ & $376^{\mathrm{a}}$ & $306^{\mathrm{b}}$ & 12.3 & 0.006 \\
\hline Ileum & 386 & 343 & 325 & 11.6 & 0.106 \\
\hline \multicolumn{6}{|c|}{ Villus height:crypt depth ratio } \\
\hline Duodenum & 0.80 & 0.79 & 0.93 & 0.02 & 0.055 \\
\hline Jejunum & $0.92^{\mathrm{a}}$ & $1.17^{\mathrm{b}}$ & $1.26^{\mathrm{b}}$ & 0.05 & 0.018 \\
\hline Ileum & 0.85 & 0.95 & 0.99 & 0.04 & 0.297 \\
\hline
\end{tabular}

A CD: control diet containing 100\% wheat starch, CN50: diet containing 50\% wheat starch and 50\% chestnut starch, CN100: diet containing $100 \%$ chestnut starch.

B P values for diet effect. SEM: standard error of the mean $(n=24)$.

$\mathrm{a}, \mathrm{b}$ : in the same line, values with the same letter are not significantly different $(\mathrm{P}>0.05)$.

Table 7

Effect of dietary proportion of chestnuts on dry matter, $\mathrm{pH}$, bacterial enzymatic activity and short chain fatty acids in the caecal contents of the piglets.

\begin{tabular}{|c|c|c|c|c|c|}
\hline & \multicolumn{3}{|l|}{$\operatorname{Diet}^{A}$} & \multirow[t]{2}{*}{$\mathrm{SEM}^{\mathrm{B}}$} & \multirow[t]{2}{*}{$\mathrm{P}^{\mathrm{B}}$} \\
\hline & $\mathrm{CD}$ & CN50 & CN100 & & \\
\hline Dry matter $\left(\mathrm{g} \mathrm{kg}^{-1}\right)$ & 122 & 121 & 86.3 & 8.51 & 0.159 \\
\hline $\mathrm{pH}$ & 6.69 & 6.47 & 6.33 & 0.07 & 0.144 \\
\hline \multicolumn{6}{|c|}{ Bacterial enzymatic activity (mg sugar $\mathrm{h}^{-1} \mathrm{~g}^{-1} \mathrm{DM}$ ) } \\
\hline Xylanolytic & 258 & 206 & 140 & 21.7 & 0.083 \\
\hline Pectinolytic & 369 & 312 & 437 & 25.1 & 0.114 \\
\hline Cellulolytic & 96.1 & 115 & 129 & 11.7 & 0.547 \\
\hline \multicolumn{6}{|l|}{$\mathrm{SCFA}\left(\mathrm{mmol}^{-1}\right)^{\mathrm{C}}$} \\
\hline $\mathrm{C} 2$ & 11.9 & 17.7 & 25.9 & 2.47 & 0.063 \\
\hline $\mathrm{C} 3$ & $5.15^{\mathrm{a}}$ & $9.43^{\mathrm{ab}}$ & $14.7^{\mathrm{b}}$ & 1.58 & 0.042 \\
\hline $\mathrm{C} 4$ & $3.50^{\mathrm{a}}$ & $4.90^{\mathrm{a}}$ & $9.84^{\mathrm{b}}$ & 1.05 & 0.025 \\
\hline IC4 & 1.13 & 1.89 & 3.65 & 0.47 & 0.075 \\
\hline IC5 & 1.33 & 1.54 & 3.10 & 0.34 & 0.062 \\
\hline Total & $23.0^{\mathrm{a}}$ & $35.5^{\mathrm{ab}}$ & $57.2^{\mathrm{b}}$ & 5.85 & 0.048 \\
\hline \multicolumn{6}{|l|}{ Molar proportion } \\
\hline $\mathrm{C} 2: \mathrm{C} 3$ & $2.40^{\mathrm{a}}$ & $1.93^{\mathrm{b}}$ & $1.82^{\mathrm{b}}$ & 0.09 & 0.008 \\
\hline $\mathrm{C} 2: \mathrm{C} 4$ & $4.04^{\mathrm{a}}$ & $3.75^{\mathrm{a}}$ & $2.73^{\mathrm{b}}$ & 0.22 & 0.031 \\
\hline $\mathrm{C} 3: \mathrm{C} 4$ & 1.75 & 1.98 & 1.53 & 0.12 & 0.276 \\
\hline C2:total & $0.53^{a}$ & $0.50^{\mathrm{a}}$ & $0.46^{\mathrm{b}}$ & 0.01 & 0.001 \\
\hline C3:total & 0.23 & 0.26 & 0.26 & 0.01 & 0.069 \\
\hline C4:total & 0.14 & 0.14 & 0.17 & 0.01 & 0.051 \\
\hline
\end{tabular}

A CD: control diet containing 100\% wheat starch, CN50: diet containing 50\% wheat starch and 50\% chestnut starch, CN100: diet containing $100 \%$ chestnut starch.

B P values for diet effect. SEM: standard error of the mean $(n=24)$.

a, b: in the same line, values with the same letter are not significantly different $(P>0.05)$.

C Short chain fatty acids: C2: acetic, C3: propionic, C4: butyric, IC4: isobutyric, IC5: isovaleric.

\subsection{Chemistry and biochemistry of caecal contents}

The effects of the experimental diets on the chemistry and biochemistry of the caecal contents are reported in Table 7. Dry matter, $\mathrm{pH}$ and bacterial fibre degradation (cellulolytic, xylanolytic and pectinolytic) in the caecum were not significantly affected by the composition of the experimental diets. Averaged across the three diets, mean DM content was $109.8 \mathrm{~g} \mathrm{~kg}^{-1}$, and mean $\mathrm{pH}$ was 6.50. There was a tendency towards lower xylanolytic activity in the piglets fed the $\mathrm{CN} 100 \operatorname{diet}(\mathrm{P}=0.083)$.

The total replacement of wheat with chestnuts (CN100 group) produced a 2.5 -fold increase in the concentration of SCFAs in the caecum of the piglets, as compared to the CD group. This increase can be attributed to higher levels of acetic (C2), propionic ( $\mathrm{C} 3$ ) and butyric ( $\mathrm{C} 4)$ acids; the concentration of $\mathrm{C} 2$ was doubled ( $\mathrm{P}=0.063)$ and the concentrations of $\mathrm{C} 3$ and $\mathrm{C} 4$ were almost trebled $(\mathrm{P}=0.042$ and $\mathrm{P}=0.025$, respectively) relative to the $\mathrm{CD}$ group. Moreover, the ratios of $\mathrm{C2}: \mathrm{C} 3$ acids, $\mathrm{C2}: \mathrm{C} 4$ acids and C2:total acids were all reduced in the CN100 group relative to the CD group; by $25 \%, 32 \%$ and $13 \%$, respectively. 
Table 8

Effect of dietary proportion of chestnuts on dry matter, pH, bacterial enzymatic activity and short chain fatty acids in the colonic contents of the piglets.

\begin{tabular}{|c|c|c|c|c|c|}
\hline & \multicolumn{3}{|l|}{$\operatorname{Diet}^{A}$} & \multirow[t]{2}{*}{$\mathrm{SEM}^{\mathrm{B}}$} & \multirow[t]{2}{*}{$\mathrm{P}^{\mathrm{B}}$} \\
\hline & $\overline{\mathrm{CD}}$ & CN50 & $\overline{\mathrm{CN}} 100$ & & \\
\hline Dry matter $\left(\mathrm{g} \mathrm{kg}^{-1}\right)$ & 213 & 189 & 185 & 7.36 & 0.248 \\
\hline $\mathrm{pH}$ & 6.95 & 6.65 & 6.62 & 0.20 & 0.106 \\
\hline \multicolumn{6}{|c|}{ Bacterial enzymatic activity (mg sugar $\mathrm{h}^{-1} \mathrm{~g}^{-1} \mathrm{DM}$ ) } \\
\hline Xylanolytic & $439^{a}$ & $399^{a}$ & $224^{\mathrm{b}}$ & 35.4 & 0.023 \\
\hline Pectinolytic & $325^{a}$ & $439^{\mathrm{ab}}$ & $577^{\mathrm{b}}$ & 41.2 & 0.035 \\
\hline Cellulolytic & 220 & 264 & 362 & 29.7 & 0.132 \\
\hline \multicolumn{6}{|l|}{$\operatorname{SCFA}\left(\mathrm{mmoll}^{-1}\right)^{\mathrm{C}}$} \\
\hline $\mathrm{C} 2$ & 21.3 & 25.6 & 24.8 & 1.59 & 0.525 \\
\hline C3 & 9.17 & 10.4 & 11.5 & 0.62 & 0.327 \\
\hline C4 & 11.4 & 12.4 & 12.0 & 0.72 & 0.865 \\
\hline IC4 & 3.01 & 3.55 & 3.65 & 0.19 & 0.359 \\
\hline IC5 & 5.17 & 4.91 & 4.55 & 0.33 & 0.768 \\
\hline Total & 50.0 & 56.8 & 56.5 & 3.09 & 0.621 \\
\hline \multicolumn{6}{|l|}{ Molar proportion } \\
\hline $\mathrm{C} 2: \mathrm{C} 3$ & 2.37 & 2.41 & 2.19 & 0.07 & 0.365 \\
\hline $\mathrm{C} 2: \mathrm{C} 4$ & 1.93 & 2.06 & 2.08 & 0.07 & 0.714 \\
\hline C3:C4 & 0.83 & 0.86 & 0.97 & 0.04 & 0.388 \\
\hline C2:total & 0.43 & 0.44 & 0.44 & 0.01 & 0.724 \\
\hline C3:total & 0.18 & 0.19 & 0.20 & 0.01 & 0.189 \\
\hline C4:total & 0.23 & 0.22 & 0.21 & 0.01 & 0.463 \\
\hline
\end{tabular}

A CD: control diet containing $100 \%$ wheat starch, CN50: diet containing $50 \%$ wheat starch and $50 \%$ chestnut starch, CN100: diet containing $100 \%$ chestnut starch.

B P values for diet effect. SEM: standard error of the mean $(n=24)$.

$\mathrm{a}, \mathrm{b}$ : in the same line, values with the same letter are not significantly different $(\mathrm{P}>0.05)$.

C Short chain fatty acids: C2: acetic, C3: propionic, C4: butyric, IC4: isobutyric, IC5: isovaleric.

Finally, there was a tendency towards an increase in the $\mathrm{C} 3$ :total and C4:total ratios ( $\mathrm{P}=0.067$ and $\mathrm{P}=0.051$, respectively) in the CN50 and CN100 groups compared to the CD group.

\subsection{Chemistry and biochemistry of colonic contents}

In the colonic contents, mean DM content was $196 \mathrm{~g} \mathrm{~kg}^{-1}$, and mean pH was 6.74 (Table 8). Dietary composition had no effect on these traits.

The total replacement of wheat with chestnuts (CN100 group) produced a 50\% reduction in bacterial xylanolytic activity in the colonic contents, but the partial replacement of wheat (CN50 group) had no significant effect on xylanolytic activity. The inclusion of chestnuts in the diet increased bacterial pectinolytic activity in the colon, but again this effect was only significant in the CN100 group. On the contrary, diet had no significant effect on bacterial cellulolytic activity in the colonic contents.

Finally, dietary composition had no effect $(\mathrm{P}>0.05)$ on the levels or molar proportions of SCFAs in the colon. The mean levels of C2, C3 and C4 acids in the colon were 23.9; 10.4 and $11.9 \mathrm{mmol}^{-1}$, respectively. The mean molar proportions of C2:total, C3:total and C4:total were $0.44,0.19$ and 0.22 , respectively.

\section{Discussion}

The fresh chestnuts used in this study had an initial dry DM content of $50 \%$, so they were dried at $40^{\circ} \mathrm{C}$ (to reach a DM content exceeding $88 \%$ ) before they were milled and mixed into the experimental diets. Starch gelatinization takes place in a range of temperatures that depends on the starch source, moisture content (Chiotelli et al., 2002) and amylose:amylopectin ratio (Correia and Beirão-da-Costa, 2012). A recent study of European chestnut cultivars (C. sativa Mill.) concluded that, at a moisture content of 50\%, the gelatinization temperature of chestnut starch ranges from 68 to $81{ }^{\circ} \mathrm{C}$ (Moreira et al., 2012). Hence, it is safe to assume that the drying procedure adopted in the present study did not modify the crystalline structure of the starch or level of RS in the chestnuts.

\subsection{Growth performance and frequency of diarrhoea}

The partial or total replacement of wheat with chestnuts did not modify feed intake, suggesting that the chestnuts were well accepted by the piglets and there were no problems concerning palatability. Nevertheless, piglets fed the control diet showed a better FCR than piglets fed the CN100 diet. This result indicates that the chestnuts were used less efficiently by the piglets compared to the wheat. 
It is known that the concentration of SCFAs in the large intestine of piglets increases with the inclusion of RS in the diet (Hedemann and Bach Knudsen, 2007). Consistent with this, higher levels of SCFAs were found in the caecum of piglets fed with chestnuts (Table 7). Relative to glucose, SCFAs have a low energy value for swine (Jorgensen et al., 1997; Bach Knudsen, 2011). Hence, resistant starches are low energy ingredients for pigs (Cervantes-Pahm et al., 2009). More recently, Gerrits et al. (2012) reported that retrograded corn starch, used as a resistant starch, has only 53\% of the digestible energy value, $73 \%$ of the metabolizable energy value, and $83 \%$ of the net energy value of enzymatically degradable starch.

The inclusion of chestnuts in the piglets' diet improved the consistency of faeces in the CN50 group as compared to the CD and CN100 groups. Where wheat was totally replaced by chestnuts, faecal scores were not significantly different from those of the control group. Bhandari et al. (2009) have recorded similar results. Raw potato starch, a RS ingredient, reduced postweaning scouring in piglets at $7 \%$, but at $14 \%$, the reverse was true. The authors attributed this effect to the large amount of undigested starch in the ileum; too high a concentration of dietary starch in the ileum impairs digestion and increases the risk of scouring. Hence, the effect of RS on faecal consistency and postweaning scouring can be either positive or negative, depending on its level of inclusion in the piglets' diet.

\subsection{Total tract apparent digestibility (TTAD)}

The addition of chestnuts to the piglets' diet had no negative effect on the TTAD of DM, even when they were the only source of starch in the diet. In fact, the TTAD of NDF was actually higher in the CN100 group, compensating for the lower TTAD of CP.

The chestnuts used in this experiment contained lower levels of CP than the equivalent weight of wheat (Table 1). Hence, when the experimental diets were formulated, extra fish meal was added to the chestnut-containing diets, in order to balance the levels of CP across the three diets. Fish meal is a highly digestible protein source for piglets (Kim and Easter, 2001), and it is implausible that it could be less digestible than the protein found in wheat. Thus, the lower TTAD of CP in the CN100 group must be explained by lower digestibility of the chestnut protein fraction and/or by an increase in endogenous nitrogen excretion in the faeces of the piglets, caused by the RS from the chestnuts. Indeed, it has already been demonstrated that RS supplementation increases faecal nitrogen excretion in piglets (Heijnen and Beynen, 1997). This effect can be attributed to a decrease in ileal nitrogen digestibility (Scrijver De et al., 1999) and an increase in bacterial nitrogen production, stemming from the stimulation of bacterial growth in the gut caused by the fermentation of undigested RS (Bird et al., 2007 and Regmi et al., 2011). The higher concentration of SCFAs in the caecum of piglets fed chestnuts in this study (Table 7) is consistent with this hypothesis, as SCFAs are also produced by RS fermentation.

When chestnuts were included in the diet, the TTAD of both NDF and ADF were increased, with the greatest enhancement in the CN100 group. This finding cannot be attributed to differing dietary levels of these non-starch polysaccharides (NSPs), as the three experimental diets contained similar amounts of NDF and ADF (Table 2). In pigs, the large intestine is the main site of NSP fermentation. $\beta$-glucans, soluble arabinoxylans, and pectins are all degraded in the caecum and proximal colon, whereas the more insoluble NSPs (e.g., cellulose and insoluble arabinoxylans) are degraded more slowly in more distal regions of the colon (Bach Knudsen, 2011).

Resistant starch may modify the microbial composition of the large intestine. For example, it can stimulate the growth of the intestinal lactobacilli (Bird et al., 2007) and bifidobacteria (Regmi et al., 2011) populations in pigs. Resistant starch may also alter the degradation of NSPs in the large intestine; shifting their utilization to more distal parts of the colon (Jonathan et al., 2013). Thus, the altered TTAD of NDF and ADF in the piglets fed the chestnut-based diets probably reflects the effect of resistant starch on the degradation of specific NSPs by the large intestinal microbiota.

\subsection{Bacterial enzymes and SCFA in the caecal and colonic contents}

The addition of chestnuts to the piglets' diet reduced xylanolytic bacterial activity and increased pectinolytic activity in the colon, with these effects being greater in the CN100 group than the CN50 group. This would seem to suggest that the RS from chestnuts, arriving in the large intestine, is able to modify bacterial activity in the colon; although it is impossible to conclude which microbial populations were stimulated or depressed. These findings are consistent with previous studies which have shown that RS from various sources can promote the growth of the bifidobacteria and lactobacilli populations in the colon of the pig, with a potential prebiotic effect (Bird et al., 2007; Bhandari et al., 2009; Regmi et al., 2011).

On the other hand, it is known that dietary non-starch polysaccharides can influence bacterial enzymatic activity in the hindgut of the pig (Varel et al., 1987). Therefore, the higher xylanolytic activity in the CD group is consistent with the presence of arabinoxylans from wheat, since these polysaccharides are the major hemicelluloses in this grain (Englyst, 1989). In the case of the CN50 and CN100 groups, the lower xylanolytic activity and the higher pectinolytic activity can be explained by a decrease in arabinoxylans and an increase in pectins when wheat was partially or totally replaced by chestnuts in the diets. Nevertheless, our data cannot confirm this hypothesis, since we have no information about the composition of non-starch polysaccharides present in the chestnuts.

The intake of chestnut starch significantly increased the concentration of SCFAs in the caecum but not in the colon. Martin et al. (2000) found that the increase in SCFA concentration in the portal venous blood of pigs occurred $4 \mathrm{~h}$ after 
a meal containing raw potato starch or high amylose maize starch, confirming that the SCFAs produced by RS fermentation are rapidly absorbed in the colon of these animals. In the present study, the contents of the colon were collected $12 \mathrm{~h}$ after feeding, so it is possible that the SCFAs were largely absorbed when the colonic contents were collected for analysis. This would explain the apparent lack of effect of the experimental diets on SCFA levels in the colon.

The type of SCFA formed in the hindgut depends on the composition of the carbohydrates available for fermentation. For example, high NSP intake provokes a considerable increase in the concentration of acetate, together with smaller increases in levels of propionate and butyrate (Wang et al., 2004). Conversely, the fermentation of RS yields higher proportions of butyric acid (Martin et al., 2000; Bird et al., 2007). In the present study, the concentration of butyrate was almost trebled in the caecum of pigs receiving the CN100 diet, and the ratio of acetate to butyrate was significantly reduced. This would appear to confirm that RS from the chestnuts was the major carbohydrate available for fermentation in the large intestine of the piglets fed the CN100 diet.

Different SCFAs in the colon are known to play different physiological roles (Mosenthin, 1998), with butyrate being the most important. Butyrate is preferentially metabolized by colonocytes to supply energy, and plays a selective antimicrobial role through its enhancement of the bifidibacteria and lactobacilli populations (Bird et al., 2007; Bhandari et al., 2009; Regmi et al., 2011). SCFAs also act as anti-diarrhoeal agents - butyrate being the most effective - by enhancing sodium and water absorption. Thus, feeding piglets chestnuts may improve the physiological conditions in their hindgut, but the effect will depend on the level of chestnuts in their diet.

\subsection{Morphology of the small intestinal mucosa and weight of the gut compartments}

The inclusion of chestnuts in the piglets' diet modified the morphology of the small intestine mucosa, causing a decrease in crypt depth in the jejunum. These results are not unexpected; the inclusion of $80 \mathrm{~g} \mathrm{~kg}^{-1}$ of raw potato starch in the diet of the weaned piglet has been shown to increase villus height, while $160 \mathrm{~g} \mathrm{~kg}^{-1}$ was shown to decrease crypt depth

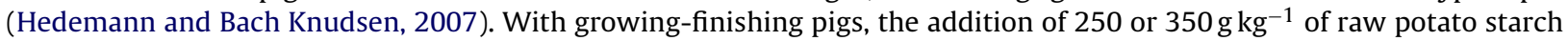
caused a decrease in villus height in the ileum, but had no effect on crypt depth (Nofrarías et al., 2007). Thus, it would seem that RS can modify the morphology of the intestinal mucosa in different ways, depending on its level of inclusion in the diet. In the present study, the villus height:crypt depth ratio was heightened in the piglets fed chestnuts, indicative of an improvement in the digestive capacity of the small intestine (Montagne et al., 2003).

The total replacement of wheat starch by chestnut starch induced a trend towards an increase in both the full and empty weight of the large intestine. Similar results were reported by Martinez-Puig et al. (2003) and Bird et al. (2007), using potato or high-amylose maize starches as sources of RS. Both authors noted that the trophic effect of RS on the large intestine was partly caused by the elongation of the colon, although in the present study, diet had no significant effect on the length of the large intestine. Hence, the increased weight may have reflected an increase in the thickness of the intestinal wall. Some argue that SCFAs - the major products of RS fermentation in the large intestine - represent the key stimuli for intestinal growth (Topping and Clifton, 2001; Martinez-Puig et al., 2003). Others believe that the mechanical action of RS itself has a greater influence on large intestine size than its fermentation products Bird et al. (2007). Using raw potato starch based diets, Nofrarías et al. (2007) found that the increased weight of the hindgut was due to hypertrophy of the tunica muscularis, mediated not only by the weight of the hindgut contents but also by its higher butyrate concentration. In the present study, piglets fed the chestnut-containing diets showed elevated levels of SCFAs (especially butyrate) in the caecum. Our results are therefore consistent with the proposed trophic effect of these fermentation products.

\section{Conclusion}

In the present study, chestnuts were well accepted by the experimental animals and could therefore be used as an alternative source of RS in the diet of weaned piglets. Nevertheless, when wheat starch was totally replaced by chestnut starch, the FCR and the TTAD of CP were impaired. Interestingly, the arrival of chestnut-derived RS in the hindgut induced a trend towards an increase in both the full and empty weight of the large intestine, and increased levels of SCFAs in the caecum. Finally, bacterial activity in the colon was modulated by the inclusion of chestnuts in the diet; xylanolytic activity was reduced, while pectinolytic activity was increased.

\section{Acknowledgements}

We would like to thank Caçador Pecuária SA for supplying the piglets used in these experiments, Reagro for providing the feed ingredients, and David Pritchett for his contribution in editing this manuscript.

\section{References}

AOAC, 1995. Official method 976.05 - Automated Kjeldahl method (Kjel-Foss Automatic). In: AOAC Official Methods of Analysis, vol. I, chapter 4, 16th ed. AOAC, p. 7. 
AOAC, 2000. Official Methods of Analysis, 17th ed. Association of Official Analytical Chemists, Arlington, VA.

Bach Knudsen, K.E., 2011. Triennial growth symposium: effects of polymeric carbohydrates on growth and development in pigs. J. Anim. Sci. 89, 1965-1980.

Bhandari, S.K., Nyachoti, C.M., Krause, D.O., 2009. Raw potato starch in weaned pig diets and its influence on postweaning scours and the molecular microbial ecology of the digestive tract. J. Anim. Sci. 87, 984-993.

Bird, A.R., Vuaran, M., Brown, I., Topping, D.L., 2007. Two high-amylose maize starches with different amounts of resistant starch vary in their effects on fermentation, tissue and digesta mass accretion, and bacterial populations in the large bowel of pigs. Br. J. Nutr. 97, 134-144.

Cervantes-Pahm, S.K., Kim, B.G., Stein, H.H., 2009. Digestible energy in resistant starch and dietary fiber sources fed to pigs. J. Anim. Sci. 87 (E-Suppl. 2), 547.

Chiotelli, E., Pilosio, G., Le Meste, M., 2002. Effect of sodium chloride on the gelatinization of starch: a multimeasurement study. Biopolymers 63, 41-58.

Correia, P., Beirão-da-Costa, M.L., 2012. Effect of drying temperatures on starch-related functional and thermal properties of chestnut flours. Food Bioprod. Process. 90, 284-294.

Englyst, H., 1989. Classification and measurement of plant polysaccharides. Anim. Feed Sci. Technol. 23, 27-42.

Falcão-e-Cunha, L., Peres, H., Freire, J.P.B., Castro-Solla, L., 2004. Effects of alfafa, wheat bran or beet pulp with or without sunflower oil, on caecal fermentation and on digestibility in the rabbit. Anim. Feed Sci. Technol. 117, 131L 149.

Freire, J.P.B., Dias, R.I.M., Cunha, L.F., Aumaitre, A., 2003. The effect of genotype and dietary fibre level on the caecal bacterial enzyme activity of young piglets: digestive consequences. Anim. Feed Sci. Technol. 109, 119-130.

Gerrits, W.J.J., Bosch, M.W., Borne,J.J.G.C., van den, 2012. Quantifying resistant starch using novel, in vivo methodology and energetic utilization of fermented starch in pigs. J. Nutr. 142, 238-244.

Hedemann, M.S., Bach Knudsen, K.E., 2007. Resistant starch for weaning pigs - effect on concentration of short chain fatty acids in digesta and intestinal morphology. Livest. Sci. 108, 175-177.

Heijnen, M.L.A., Beynen, A., 1997. Consumption of retrograded (RS3) but not uncooked (RS2) resistant starch shifts nitrogen excretion from urine to faeces in cannulated piglets. J. Nutr. $127,1828-1832$.

INE, 2011. Agricultural Statistics. Instituto Nacional de Estatística, I.P, Lisboa Portugal.

Jonathan, M.C., Haenen, D., Souza da Silva, C., Bosch, G., Schols, H.A., Gruppen, H., 2013. Influence of a diet rich in resistant starch on the degradation of non-starch polysaccharides in the large intestine of pigs. Carbohydr. Polym. 93, 232-239.

Jorgensen, H., Larsen, T., Zhao, X.Q., Eggum, B.O., 1997. The energy value of short-chain fatty acids infused into the caecum of pigs. Br. J. Nutr. 77, $745-756$.

Kim, S.W., Easter, R.A., 2001. Nutritional value of fish meals in the diet for young pigs. J. Anim. Sci. 79, 1829-1839.

Littell, R.C., Henry, P.R., Ammerman, C.B., 1998. Statistical analysis of repeated measures data using SAS procedures. J. Anim. Sci. 76, $1216-1231$.

Marquardt, R.R., Jin, L.Z., Kim, J.W., Fang, L., Frohlich, A.A., Baidoo, S.K., 1999. Passive protective effect of egg-yolk antibodies against enterotoxigenic Escherichia coli K88+ infection in neonatal and early-weaned piglets. FEMS Immunol. Med. Microbiol. 23, $283-288$.

Martin, L.J.M., Dumon, H.J.W., Lecannu, G., Champ, M.M.J., 2000. Potato and high-amylose maize starches are not equivalent producers of butyrate for the colonic mucosa. Br. J. Nutr. 84, 689-696.

Martinez-Puig, D., Pérez, J.F., Castillo, M., Andaluz, A., Anguita, M., Morales, J., Gasa, J., 2003. Consumption of raw potato starch increases colon length and faecal excretion of purine bases in growing pigs. J. Nutr. 133, 134-139.

Míguelez, J.M., Bernárdez, M.M., Queijeiro, J.M.G., 2004. Composition of varieties of chestnuts from Galicia (Spain). Food Chem. 84, 401-404.

Montagne, L., Pluske, J.R., Hampson, D.J., 2003. A review of interaction between dietary fibre and intestinal mucosa, and their consequences on digestive health in young non-ruminant animals. Anim. Feed Sci. Technol. 16, 1332-1338.

Moreira, R., Chenlo, F., Torres, M.D., Rama, B., 2012. Influence of the chestnuts drying temperature on the rheological properties of their doughs. Food Bioprod. Process. 91, 7-13.

Morel, P.O.H., Melai, J., Eady, S.L., Coles, G.D., 2005. Effect of non-starch polysaccharides and resistant starch on mucin secretion and endogenous amino acid losses in pigs. J. Anim. Sci. 18, 1634-1641.

Mosenthin, R., 1998. Physiology of small and large intestine of swine - review. Asian J. Anim. Sci. 11, 608-619.

Nofrarías, M., Martínez-Puig, D., Pujols, D.V.M.J., Majó, N., Pérez, J.F., 2007. Long-term intake of resistant starch improves colonic mucosal integrity and reduces gut apoptosis and blood immune cells. Nutrition 23, 861-870.

NRC, 1998. Nutrient Requirements of Swine, 10th ed. National Academic Press, Washington, DC.

Pizzoferrato, L., Rotilio, G., Pai, M., 1999. Modification of structure and digestibility of Chestnut starch upon cooking: a solid state ${ }^{13} \mathrm{C}$ CP MAS NMR and enzymatic degradation study. J. Agric. Food Chem. 47, 4060-4063.

Regmi, P.R., Metzler-Zebeli, B.U., Ganzle, M.G., van Kempen, T.A.T.G., 2011. Starch with high amylose content and low in vitro digestibility increases intestinal nutrient flow and microbial fermentation and selectively promotes bifidobacteria in pigs. J. Nutr. 141, 1273-1280.

Rideout, P.R., Liu, Q., Wood, P., Fan, M.Z., 2008. Nutrient utilization and intestinal fermentation are differentially affected by the consumption of resistant starch varieties and conventional fibres in pigs. Br. J. Nutr. 99, 984-992.

Robertfroid, M.B., 2001. Prebiotics: preferential substrates for specific germs? Am. J. Clin. Nutr. 73, 406S-409S.

SAS, 1991. SAS Systems for Linear Models, 3rd ed. SAS Institute Inc., Cary, NC.

Scrijver De, R., Vanhoof, K., Ginste, V.J., 1999. Nutrient utilization in rats and pigs fed enzyme resistant starch. Nutr. Res. 19, $1349-1361$.

Thivend, P., Mercier, C., Guilbot, A., 1965. Dosage de l'amidon dans les milieu complexes. Ann. Biol. Anim. Biochem. Biophys. 5, 513-526.

Topping, D.L., Clifton, P.M., 2001. Short-chain fatty acids and human colonic function: roles of resistant starch and nonstarch polysaccharides. Physiol. Rev. 81, 1031-1064.

Van Soest, P.J., Robertson, J.B., Lewis, B.A., 1991. Carbohydrate methodology, metabolism and nutritional implications in dairy cattle. J. Dairy Sci. 74, 3583-3597.

Varel, V.H., Robinson, I.M., Jung, H.J., 1987. Influence of dietary fiber on xylanolytic and cellulolytic bacteria of adult pigs. Appl. Environ. Microbiol. 53, 22-26.

Wang, J.F., Zhut, Y.H., Li, D.F., Wang, Z., Jensen, B.B., 2004. In vitro fermentation of various fiber and starch sources by pig faecal inocula. J. Anim. Sci. 82, 2615-2622.

Williams, B.A., Verstegen, M.W.A., Tamminga, S., 2001. Fermentation in the large intestine of single-stomached animals and its relationship to animal health. Nutr. Res. Rev. 14, 207-227. 